\title{
Stosowanie skojarzenia beta-adrenolityku i inhibitora konwertazy angiotensyny w terapii nadciśnienia tętniczego spojrzenie hipertensjologa
}

\author{
Aleksander Prejbisz \\ Klinika Nadciśnienia Tętniczego, Instytut Kardiologii, Warszawa
}

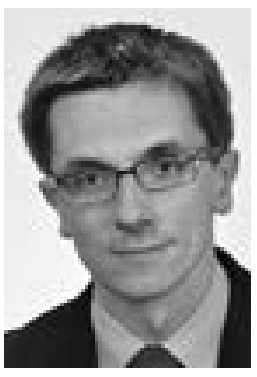

WPROWADZENIE

Historia stosowania $\beta$-adrenolityków w terapii nadciśnienia tętniczego sięga już ponad 50 lat. W 1962 roku Black opisał właściwości farmakologiczne pierwszego $\beta$-adrenolityku — pronethanolu. Dwa lata później Prichard i Gillam jako pierwsi wykazali skuteczność hipotensyjną propranololu u chorych na nadciśnienie tętnicze. Już 3 lata później, bo w 1967 roku, ukazała się pierwsza polska praca oceniająca skuteczność hipotensyjną propranololu (Baczko, Dąbrowska, Wocial). Chociaż omawiana grupa leków miała swoje „wzloty i upadki”, obecnie leki blokujące receptory $\beta$-adrenergiczne należą do jednych z najczęściej wykorzystywanych preparatów w terapii nadciśnienia tętniczego. Wyniki badania Pol-Fokus wskazują z kolei, że $\beta$-adrenolityki są najczęściej stosowane w skojarzeniu $z$ inhibitorem konwertazy angiotensyny (ACEI). W niniejszym artykule przedstawiono przypadek chorego, u którego zastosowano w terapii nadciśnienia tętniczego $\beta$-adrenolityk i ACEI, a także omówiono pozycję $\beta$-adrenolityków oraz połączenia $\beta$-adrenolityku i ACEI (na przykładzie skojarzenia bisoprololu i perindoprilu) w odniesieniu do wybranych badań klinicznych, wytycznych European Society of Hypertension/European Society of Cardiology (ESH/ESC) z 2013 roku oraz wytycznych Polskiego Towarzystwa Nadciśnienia Tętniczego (PTNT) z 2015 roku [1-5].

\section{PACJENT Z NIESKUTECZNIE LECZONYM NADCIŚNIENIEM TĘTNICZYM Opis przypadku}

Mężczyzna w wieku 56 lat, z nadciśnieniem tętniczym rozpoznanym i leczonym od roku, zgłosił się do lekarza rodzinnego na wizytę kontrolną. Nadciśnienie tętnicze rozpoznano rok wcześniej i rozpoczęto terapię ACEI (ramipril $5 \mathrm{mg}$ ). W sporadycznie wykonywanych domowych pomiarach ciśnienia tętniczego w ostatnim okresie wartości mieściły się w zakresie 130-150/80-95 mm Hg.

Chory nie zgłaszał żadnych dolegliwości. Ojciec pacjenta choruje na nadciśnienie tętnicze, w wieku 68 lat przebył zawał serca. Chory jest kierownikiem działu obsługi klienta, pracuje średnio 8-9 godzin dziennie, 5 dni w tygodniu, swoją pracę uważa za związaną z dużą odpowiedzialnością i określa ją jako „stresującą". Pacjent nie stosuje regularnej aktywności fizycznej. Nigdy nie palił tytoniu. Kilka razy w miesiącu wypija ok. 1000-1500 ml piwa.

\section{Badanie przedmiotowe}

W badaniu przedmiotowym zanotowano następujące parametry: nadwaga (wskaźnik masy ciała $28 \mathrm{~kg} / \mathrm{m}^{2}$ ), obwód pasa — $97 \mathrm{~cm}$, tętno miarowe (92/min), ciśnienie tętnicze w pozycji siedzącej - 142/91 mm Hg (średnia z trzech pomiarów), po 1. i 3. minutach pionizacji odpowiednio - 146/93 mm Hg i 145/93 mm Hg, takie samo na obu kończynach górnych, brak innych nieprawidłowości.

\section{Postępowanie}

Choremu zalecono ponowną wizytę lekarską za 2 tygodnie, po wykonaniu domowych pomiarów ciśnienia tętniczego w celu oceny skuteczności leczenia hipotensyjnego w warunkach codziennej aktywności (wykonanie całodobowej rejestracji ciśnienia tętniczego nie było możliwe). Choremu wydano szczegółowe zalecenia dotyczące zasad przeprowadzania domowych pomiarów ciśnienia tętniczego.

\footnotetext{
Adres do korespondencji:

dr hab. n. med. Aleksander Prejbisz, Klinika Nadciśnienia Tętniczego, Instytut Kardiologii, ul. Alpejska 42, 04-628 Warszawa, tel: +48 223434346 , faks: +48223434 517, e-mail: aprejbisz@ikard.pl

Suplement: Copyright (C) „Via Medica sp. z o.o." sp.k. 2017
} 


\section{Wizyta kontrolna po 2 tygodniach}

Podczas kolejnej wizyty (2 tygodnie od poprzedniej) ciśnienie tętnicze (wartości średnie z 3 pomiarów) w pozycji siedzącej wynosiło 144/92 mm Hg, a wartość ciśnienia tętniczego w pomiarach domowych — 154/95 mm Hg (średnia z tygodniowego okresu pomiarów przed wizytą, wyższe wartości ciśnienia tętniczego stwierdzano w godzinach popołudniowych, we wszystkich pomiarach częstość rytmu serca wynosiła > 80/min).

Zmodyfikowano zatem leczenie pacjenta — odstawiono ramipril, włączono do terapii perindopril $5 \mathrm{mg}$ i bisoprolol 2,5 mg, stosowane raz dziennie. Choremu zalecono wizyte kontrolną za 4 tygodnie.

\section{Wizyta kontrolna po 8 tygodniach}

Na kolejną wizytę chorych zgłosił się 8 tygodni od poprzedniej. Ciśnienie tętnicze (wartości średnie z 3 pomiarów) w pozycji siedzącej wynosiło 135/87 mm Hg, częstość rytmu serca - 82/min, wartość ciśnienia tętniczego w pomiarach domowych - 138/87 mm Hg (średnia z tygodniowego okresu pomiarów przed wizytą). Chory ograniczył dosalanie potraw, zmniejszył ilość wypijanego jednorazowo alkoholu. Zwiększono dawkę perindoprilu i bisoprololu, zastosowano preparat złożony bisoprolol + perindopril (5 mg + $10 \mathrm{mg}$ ).

\section{Wizyta kontrolna po 8 tygodniach od modyfikacji leczenia}

Na kolejną wizytę chory zgłosił się po 8 tygodniach. Wartości ciśnienia tętniczego w pomiarach klinicznych wynosiły 130/81 mm Hg (średnia z trzech pomiarów), częstość rytmu serca $-71 / \mathrm{min}$, a wartość ciśnienia tętniczego w pomiarach domowych - 129/79 mm Hg (średnia z tygodniowego okresu pomiarów przed wizytą).

\section{KOMENTARZ}

W poniższym komentarzu przede wszystkim omówiono miejsce $\beta$-adrenolityków w terapii nadciśnienia tętniczego oraz miejsce skojarzenia $\beta$-adrenolityku i ACEI u pacjentów z nadciśnieniem tętniczym bez wspótistniejącej choroby serca.

\section{Skuteczność hipotensyjna $\beta$-adrenolityków}

Leki $\beta$-adrenolityczne odznaczają się dużą skutecznością hipotensyjną zarówno w monoterapii, i jak w leczeniu skojarzonym nadciśnienia tętniczego.

Warto zwrócić uwagę na interesujące wyniki fińskiego badania znanego pod akronimem GENRES [6], którym objęto 208 mężczyzn chorych na nadciśnienie tętnicze, w wieku 35-60 lat (średni wiek 51 lat) — zaprezentowany w niniejszym artykule pacjent cechował się podobną charakterystyką kliniczną do chorych poddanych badaniu GENRES. Stwierdzono porównywalny efekt hipotensyjny bisoprololu, amlodipiny, hydrochlorotiazydu i losartanu, zarówno w pomiarach klinicznych (ryc. 1), jak i w całodobowej rejestracji ciśnienia tętniczego [6].

Interesujące są również wyniki metaanalizy Walda i wsp. [7], w której porównano skuteczność leczenia hipo-

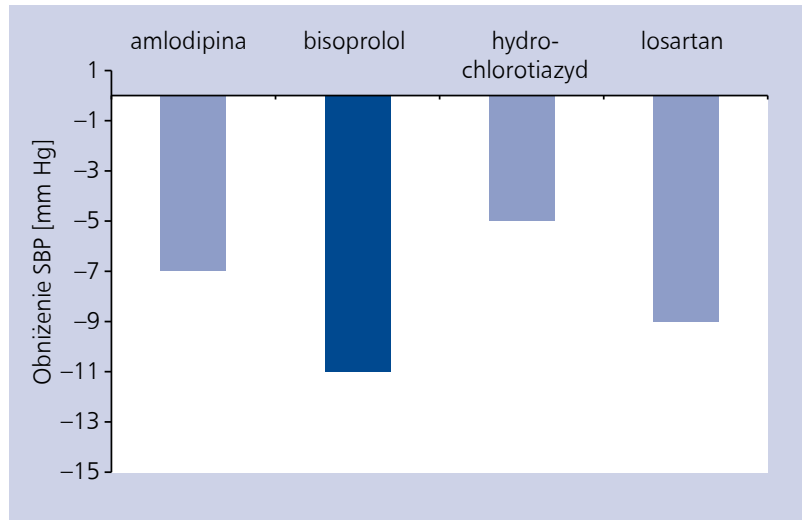

Rycina 1. Badanie GENRES - porównanie skuteczności hipotensyjnej bisoprololu, amlodipiny, hydrochlorotiazydu i losartanu w 4-tygodniowej obserwacji u mężczyzn w wieku 35-60 lat. Obniżenie skurczowego ciśnienia tętniczego (SBP) w pomiarach klinicznych; na podstawie [6]

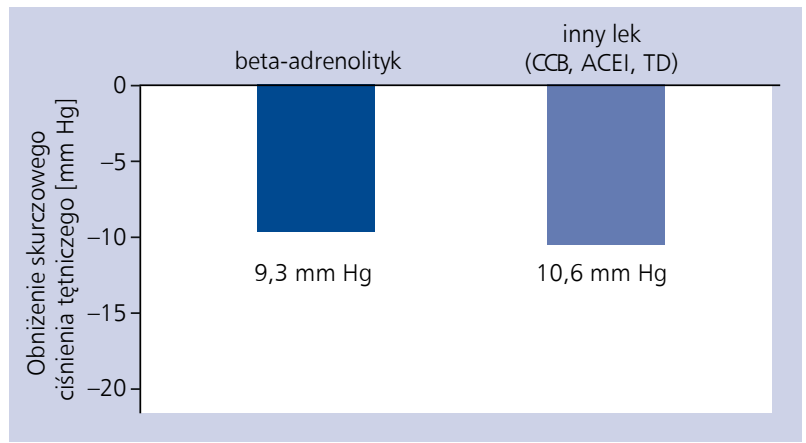

Rycina 2. Metaanaliza Walda i wsp. — porównanie skuteczności hipotensyjnej $\beta$-adrenolityków i antagonistów wapnia (CCB), inhibitorów konwertazy angiotensyny (ACEI) oraz diuretykòw tiazydowych (TD) stosowanych w monoterapii; na podstawie [7]

tensyjnego za pomocą monoterapii i leczenia skojarzonego. Do metaanalizy włączono 42 badań, którymi objęto prawie 11 tysięcy chorych. Oceniono skuteczność stosowania czterech grup leków hipotensyjnych w monoterapii (diuretyków tiazydowych, antagonistów wapnia, $\beta$-adrenolityków i ACEl), a także skuteczność hipotensyjną w przypadku zwiększenia dawki leku lub dołączenia kolejnego preparatu hipotensyjnego. Wykazano, że stosowanie $\beta$-adrenolityków w monoterapii charakteryzuje się porównywalną skutecznością hipotensyjną ze stosowaniem innych grup leków hipotensyjnych (diuretyków, antagonistów wapnia, ACEI) (ryc. 2). Udowodniono też, że dołączenie do któregokolwiek leku preparatu z innej grupy wiąże się $z$ efektem hipotensyjnym, który w przybliżeniu stanowi sumę efektów hipotensyjnych obu tych leków stosowanych w monoterapii. Stwierdzono również, że podwojenie standardowej dawki leku hipotensyjnego w monoterapii jest związane z 5-krotnie mniej wyrażonym efektem hipotensyjnym w porównaniu z dołączeniem drugiego leku hipotensyjnego do stosowanego już preparatu hipotensyjnego w standardowej dawce [7]. 


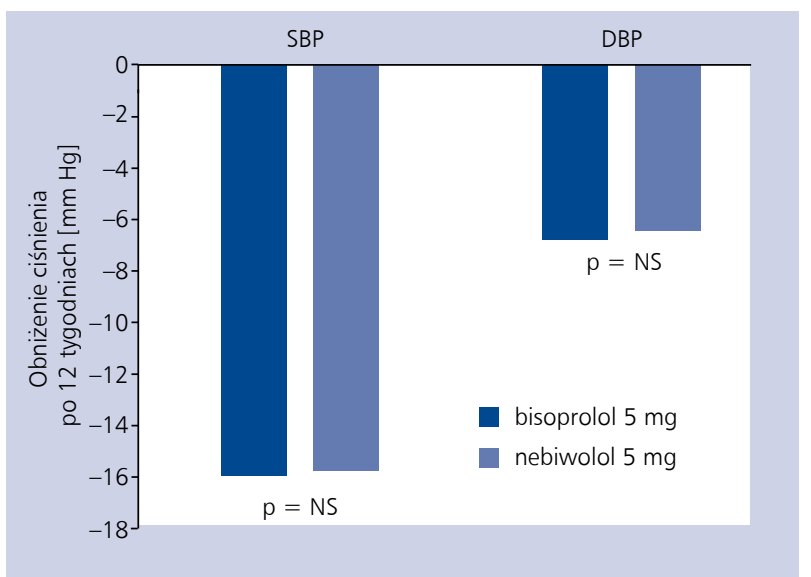

Rycina 3. Badanie NEBIS - wpływ stosowania bisoprololu lub nebiwololu na obniżenie skurczowego (SBP) i rozkurczowego (DBP) ciśnienia tętniczego; na podstawie [9]

Należy również zwrócić uwagę na wyniki najnowszej metaanalizy Cochrane [8]. Oceniono w niej skuteczność hipotensyjną $\beta$-adrenolityków kardioselektywnych (w tym m.in. bisoprololu). Wykazano, że stosowanie tych leków u chorych na łagodne i umiarkowane nadciśnienie tętnicze wiąże się z obniżeniem ciśnienia tętniczego średnio o 10/8 mm Hg. Kardioselektywne $\beta$-adrenolityki obniżały w porównywalnym stopniu skurczowe i w większym stopniu rozkurczowe ciśnienie tętnicze w porównaniu z diuretykami, ACEl i antagonistami receptora angiotensyny [8]. Omawiając skuteczność hipotensyjną $\beta$-adrenolityków kardioselektywnych, trzeba też wspomnieć o badaniu NEBIS [9], do którego włączono 273 chorych na nadciśnienie tętnicze. Wykazano w nim, że bisoprolol (5 mg) i nebiwolol (5 mg) charakteryzują się porównywalnym efektem hipotensyjnym w 12-tygodniowej obserwacji (ryc. 3). Nie stwierdzono również istotnych różnic w częstości występowania zdarzeń niepożądanych [9].

\section{Beta-adrenolityki w terapii nadciśnienia} tętniczego - wytyczne ESH/ESC 2013 i PTNT 2015 W zaleceniach ESH/ESC z 2013 roku uznano, że $\beta$-adrenolityki, obok diuretyków, antagonistów wapnia, ACEI oraz antagonistów receptora angiotensyny II "nadają się i są zalecane do rozpoczynania i kontynuowania leczenia hipotensyjnego, zarówno w monoterapii, jak i w połączeniach" (klasa zaleceń I, poziom wiarygodności danych A) [1].

W zaleceniach PTNT z 2015 roku uznano, że $\beta$-adrenolityki, obok diuretykòw, antagonistów wapnia, ACEI oraz antagonistów receptora angiotensyny II należą do leków pierwszego rzutu, „w przypadku których udowodniono korzystny wpływ na redukcję śmiertelności sercowo-naczyniowej i/lub ryzyka incydentów sercowo-naczyniowych" [5].

Eksperci polscy zalecają stosowanie $\beta$-adrenolityków w nadciśnieniu tętniczym u chorych z [5]:

- tachykardią i/lub zaburzeniami rytmu serca;
Tabela 1. Stany kliniczne, w których (w leczeniu nadciśnienia tętniczego) należy preferować $\beta$-adrenolityki jako leki pierwszego lub drugiego wyboru wg wytycznych Polskiego Towarzystwa Nadciśnienia Tętniczego (PTNT) z 2015 r. [5]

\begin{tabular}{l}
\multicolumn{1}{c}{ Lek pierwszego wyboru } \\
\hline Choroba niedokrwienna serca \\
Niewydolność serca (tylko karwedilol, bisoprolol, metoprolol XR/CR, \\
nebiwolol) \\
Migotanie przedsionków utrwalone \\
Tachyarytmie \\
Tętniak rozwarstwiający aorty \\
Jaskra
\end{tabular}

\section{Lek drugiego wyboru}

Ciąża (preferowany labetalol [trudno dostępny w Polsce], z innych

$\beta$-adrenolityków tylko metoprolol)

Zaburzenia potencji (tylko nebiwolol)

- objawami krążenia hiperkinetycznego, szczególnie u osób młodszych;

- współistniejącą niewydolnością serca;

- współistniejącą chorobą wieńcową, zwłaszcza po przebytym zawale serca.

Autorzy wytycznych PTNT z 2015 roku wskazali, że w leczeniu nadciśnienia tętniczego indywidualizacja terapii odgrywa istotną rolę. Zaznaczono, że „ważne znaczenie ma wybór terapii pierwszego rzutu, ze względu na potencjalne korzyści hipotensyjne udokumentowane w dużych badaniach klinicznych w przypadku określonych powikłań sercowo-naczyniowych i nerkowych oraz zaburzeń metabolicznych w nadciśnieniu tętniczym lub możliwość osiągnięcia dodatkowych korzyści lub uniknięcia działań niepożądanych w przypadku chorób towarzyszących, wynikających ze znajomości farmakologii leków hipotensyjnych". Zaznaczono również, że „rozpowszechnienie terapii skojarzonej [ok. 85\% chorych - przyp. aut.] sprawiło, że zalecenia indywidualizacji terapii hipotensyjnej obejmują również leki drugiego rzutu w określonych sytuacjach klinicznych" (tab. 1) [5].

\section{Beta-adrenolityki w terapii nadciśnienia tętniczego - wybrane stany kliniczne}

Autorzy wytycznych ESH/ESC z 2013 roku poświęcili sporo uwagi wielu stanom klinicznym współistniejącym z nadciśnieniem tętniczym. Omówiono różnice w postępowaniu w nadciśnieniu tętniczym, a zwłaszcza możliwość zastosowania poszczególnych grup leków hipotensyjnych. Poniżej podsumowano zalecenia ESH/ESC z 2013 roku dotyczące wybranych stanów klinicznych w odniesieniu do możliwości zastosowania $\beta$-adrenolityków [1].

- Osoby w wieku podeszłym — w badaniach z randomizacją wykazano korzyści ze stosowania wszystkich głównych grup leków hipotensyjnych, w tym $\beta$-adrenolityków; 
zaleca się stosowanie leków hipotensyjnych dowolnej klasy (włączając w to $\beta$-adrenolityki) [1].

- Cukrzyca - podsumowano, że " $\beta$-adrenolityki, mimo potencjalnej możliwości pogorszenia wrażliwości na insulinę, w terapii skojarzonej są użyteczne w kontroli ciśnienia tętniczego, zwłaszcza u pacjentów z chorobą wieńcową oraz z niewydolnością serca" [1].

- Zespół metaboliczny - zalecono, by $\beta$-adrenolityki stosować jako leki dodatkowe i w małych dawkach [1].

- Choroba naczyniowo-mózgowa - zaleca się wszystkie schematy leczenia, pod warunkiem, że są skuteczne hipotensyjnie, w tym również $\beta$-adrenolityki [1].

- Choroby serca - wskazano na istotne miejsce w leczeniu pacjentów z nadciśnieniem tętniczym po przebytym zawale serca oraz z niewydolnością serca; są preferowanymi lekami u chorych z objawami dławicy piersiowej; mogą być rozważone w leczeniu objawowym u osób z niewydolnością serca z zachowaną funkcją skurczową oraz u chorych z ryzykiem wystąpienia de novo lub nawrotu migotania przedsionków w przypadku współistnienia niewydolności serca [1].

- Zwiększona sztywność tętnic - można stosować lek z dowolnej klasy [1].

- Choroba tętnic obwodowych - biorąc pod uwagę wyniki dwóch dużych metaanaliz, posumowano, że „w leczeniu nadciśnienia tętniczego u pacjentów z chorobą tętnic obwodowych można rozważyć $\beta$-adrenolityki, gdyż nie wydaje się, aby ich zastosowanie wiązało się z zaostrzeniem objawów choroby tętnic obwodowych, chociaż konieczna jest staranna obserwacja" [1].

\section{Beta-adrenolityki w leczeniu skojarzonym nadciśnienia tętniczego}

W zaleceniach ESH/ESC z 2013 roku szczegółowo omówiono zasady leczenia skojarzonego nadciśnienia tętniczego. Do możliwych połączeń lekowych opartych na $\beta$-adrenolitykach zaliczono skojarzenie [5]:

- $\beta$-adrenolityku i antagonisty wapnia;

- $\beta$-adrenolityku i ACEI/antagonisty receptora angiotensyny II.

W zaleceniach PTNT z 2015 roku również dokładnie opisano zasady leczenia skojarzonego nadciśnienia tętniczego. Do podstawowych zaliczono następujące połączenia oparte na $\beta$-adrenolitykach [5]:

- $\beta$-adrenolityk i ACEI;

- $\beta$-adrenolityk i antagonista wapnia.

Jako przydatne połącznie, z pewnymi ograniczeniami, określono skojarzenie $\beta$-adrenolityku z diuretykiem tiazydowym/tiazydopodobnym. Eksperci zwrócili uwagę, że chociaż połączenie to było równie skuteczne jak inne skojarzenia leków w kilku próbach klinicznych w zakresie zmniejszenia ryzyka sercowo-naczyniowego, to w porównaniu z innymi powoduje większą liczbę nowych przypadków cukrzycy [5].

\section{Inhibitory konwertazy angiotensyny w terapii nadciśnienia tętniczego}

W prezentowanym przypadku u chorego stosowano ACEI. Zmieniono przyjmowany wcześniej przez pacjenta ramipril na perindopril. Należy również zaznaczyć, że nie wszystkie ACEI charakteryzują się porównywalnym efektem hipotensyjnym i długością trwania tego efektu.

W badaniu Myersa [10] opartym na całodobowej rejestracji ciśnienia tętniczego, wykazano, że zastosowany u przedstawionego chorego ACEI — perindopril - cechuje się istotnym efektem hipotensyjnym zarówno po 6, jak i 24 godzinach od przyjęcia leku, co może wskazywać na jego obejmujący całą dobę czas działania. Udowodniono również, że poszczególne ACEI różnią się między sobą tzw. wskaźnikiem through-to-peak (T/P), który pozwala ocenić, czy obniżenie ciśnienia tętniczego obejmuje cały okres doby. Perindopril charakteryzuje się wysokim współczynnikiem T/P mieszczącym się w zakresie 75-100\%, natomiast wskaźnik ten nie przekracza $70 \%$ w odniesieniu do większości innych preparatów z tej grupy [10].

Warto też zwrócić uwagę na wyniki badania CONFIDENCE [11] — wieloośrodkowego, prospektywnego programu obserwacyjnego, którego celem była ocena skuteczności hipotensyjnej w warunkach codziennej praktyki klinicznej u pacjentów pozostających pod opieką lekarzy rodzinnych oraz przychodni specjalistycznych. Badaniem objęto 8298 chorych na nadciśnienie tętnicze, zarówno do tej pory nieleczonych (56\% badanej grupy), jak i chorych z dotychczas niezadowalająco kontrolowanym ciśnieniem tętniczym (44\%). Pacjenci otrzymywali perindopril przez 12 tygodni. W trakcie obserwacji wykazano istotne zmniejszenie wartości ciśnienia tętniczego o 19/10 mm Hg. Na uwagę zasługuje również podgrupa chorych z wyjściowo wysokimi wartościami ciśnienia tętniczego (skurczowe > $170 \mathrm{~mm} \mathrm{Hg}$ ), w której uzyskano obniżenie ciśnienia o 36/15 mm Hg [11].

Należy w tym miejscu również wspomnieć o badaniu PREFER [12], do którego włączono 824 chorych na nadciśnienie tętnicze leczonych dotychczas nieskutecznie za pomocą ACEI (w monoterapii lub w terapii skojarzonej). W 3-miesięcznej obserwacji wykazano, że zastąpienie dotychczas nieskutecznego ACEI — perindoprilem (5-10 mg) wiązało się z istotnym obniżeniem ciśnienia tętniczego (o 26/13 mm Hg) i ciśnienia tętna, a także uzyskaniem docelowych wartości ciśnienia tętniczego u prawie połowy chorych [12].

Zgodnie z zaleceniami ESH/ESC z 2013 roku ACEI należą do głównych grup leków stosowanych przy rozpoczynaniu leczenia hipotensyjnego. Sytuacje, w których bardziej korzystne może być użycie ACEI niż innych grup leków hipotensyjnych, przedstawiono w tabeli 2 [1]. Wybrany preparat ACEI — perindopril - oprócz wysokiej skuteczności hipotensyjnej charakteryzuje się również wykazanym w badaniach klinicznych wpływem na redukcję śmiertelności.

Omawiając wpływ leczenia ACEI na zmniejszenie śmiertelności u chorych na nadciśnienie tętnicze należy 
Tabela 2. Stany przemawiające za stosowaniem inhibitorów konwertazy angiotensyny wg wytycznych European Society of Hypertension/European Society of Cardiology (ESH/ESC) z 2013 r. [1]

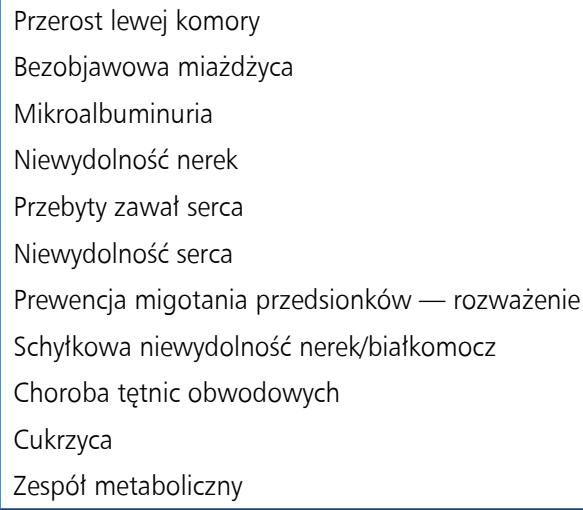

przywołać wyniki dużej metaanalizy Laury van Vark i wsp. [13]. Wykazano w niej, że terapia ACEI lub sartanami wiąże się z 5-procentową redukcją śmiertelności z jakiejkolwiek przyczyny ( $p=0,032)$ oraz z 7-procentowym zmniejszeniem śmiertelności z przyczyn sercowo-naczyniowych $(p=0,018)$. W osobnej analizie stwierdzono, że leczenie ACEI koreluje z 10-procentową redukcją śmiertelności z jakiejkolwiek przyczyny ( $p=0,004)$ oraz z 9,1-procentowym zmniejszeniem śmiertelności z przyczyn sercowo-naczyniowych $(p=0,051)$. Nie zaobserwowano wpływu sartanów na zmniejszenie śmiertelności z jakiejkolwiek przyczyny i śmiertelności z przyczyn sercowo-naczyniowych. Należy podkreślić, że w omawianej analizie korzystny wpływ stosowania ACEI na redukcję śmiertelności z jakiejkolwiek przyczyny wynikał głównie ze zmniejszenia śmiertelności z jakiejkolwiek przyczyny w trzech badaniach z zastosowaniem perindoprilu - ADVANCE, ASCOT i HYVET (ryc. 4) [13].

\section{Skojarzenie $\beta$-adrenolityku z ACEI w terapii nadciśnienia tętniczego}

Wyniki dużego programu Pol-Fokus, którym objęto 12375 chorych na nadciśnienie tętnicze pozostających pod opieką lekarzy rodzinnych i specjalistów (kardiolodzy i hipertensjolodzy), wskazują, że wśród osób leczonych skojarzeniem dwóch leków hipotensyjnych, najczęściej (35\%) stosowanym połączeniem leków hipotensyjnych jest $\beta$-adrenolityk i lek hamujący układ renina-angiotensyna. Wśród chorych stosujących 3 leki hipotensyjne $\beta$-adrenolityk i lek hamujący układ renina-angiotensyna przyjmowało $63 \%$ pacjentów. U większości tych chorych (odpowiednio 73\% i 68\%) $\beta$-adrenolityk był łączony z ACEI. Interesujące jest również to, że wśród osób stosujących dwa i więcej leków hipotensyjnych chorzy, którzy otrzymywali $\beta$-adrenolityk, w 92\% przyjmowali też lek hamujący układ renina-angiotensyna. Można więc podsumować, że w leczeniu skojarzonym nadciśnienia tętniczego prawie

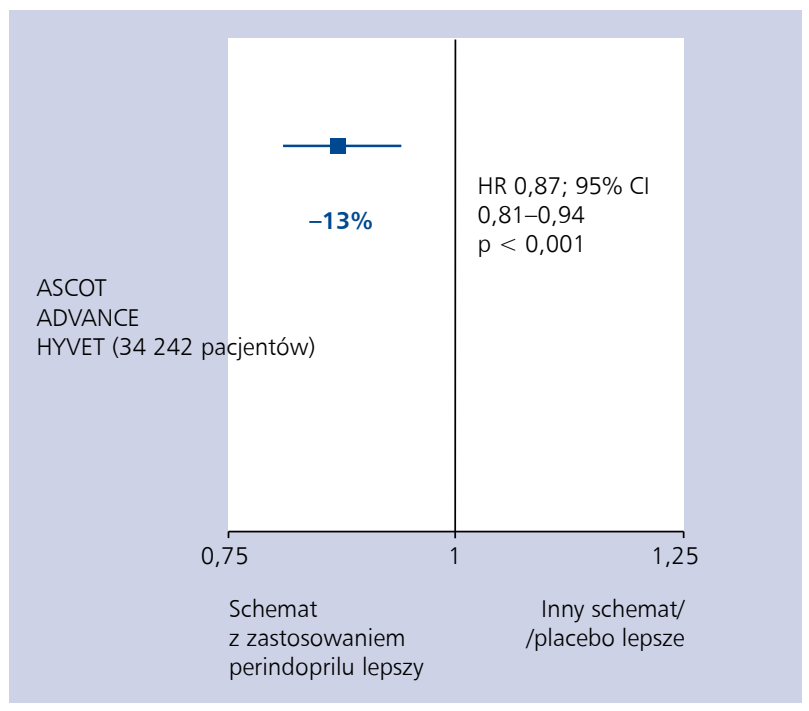

Rycina 4. Metaanaliza badań van Vark i wsp. z wykorzystaniem leków hamujących układ renina-angiotensyna. Wpływ stosowania schematu obejmującego inhibitor konwertazy angiotensyny (peridnodopril) na śmiertelność z jakiejkolwiek przyczyny; $\mathrm{Cl}$ - przedział ufności; HR — hazard względny; na podstawie [13]

zawsze $\beta$-adrenolityk jest stosowany z lekiem hamującym układ renina-angiotensyna (w większości z ACEI) [14, 15].

Powstaje zatem pytanie, dlaczego tak chętnie $\beta$-adrenolityki są stosowane w skojarzeniu z ACEl? Z pewnością jedną z głównych przesłanek jest udowodnione działanie kardioprotekcyjne u pacjentów z rozpoznaną chorobą serca - zastosowanie to zostało omówione w artykule dra hab. n. med. Filipa Szymańskiego, zamieszczonym w niniejszym suplemencie do czasopisma „Kardiologia Polska”.

Należy podkreślić, że skojarzenie $\beta$-adrenolityków z lekiem hamującym układ renina-angiotensyna charakteryzuje się większą skutecznością hipotensyjną niż stosowanie poszczególnych leków osobno. W rodzimym badaniu Madeja i wsp. [16], któremu poddano chorych na nadciśnienie tętnicze, wykazano wyższą skuteczność hipotensyjną leczenia skojarzonego bisoprololem i perindoprilem niż stosowanie tych leków w monoterapii (ryc. 5). Z kolei w innym, dużym badaniu NAC-MD-01 obejmującym 4161 chorych na nadciśnienie tętnicze potwierdzono skuteczność hipotensyjną skojarzenia $\beta$-adrenolityku i leku hamującego układ renina-angiotensyna w postaci preparatu złożonego [17]. Należy przypomnieć, że zarówno bisoprolol, jak i perindopril charakteryzują się 24-godziną skutecznością hipotensyjną.

\section{PODSUMOWANIE}

W prezentowanym przypadku zastosowanie u 56-letniego mężczyzny, nieskutecznie leczonego w ramach monoterapii, preparatu złożonego opartego na ACEI i $\beta$-adrenolityku wiązało się z poprawą kontroli nadciśnienia tętniczego i uzyskaniem docelowych wartości ciśnienia tętniczego. 


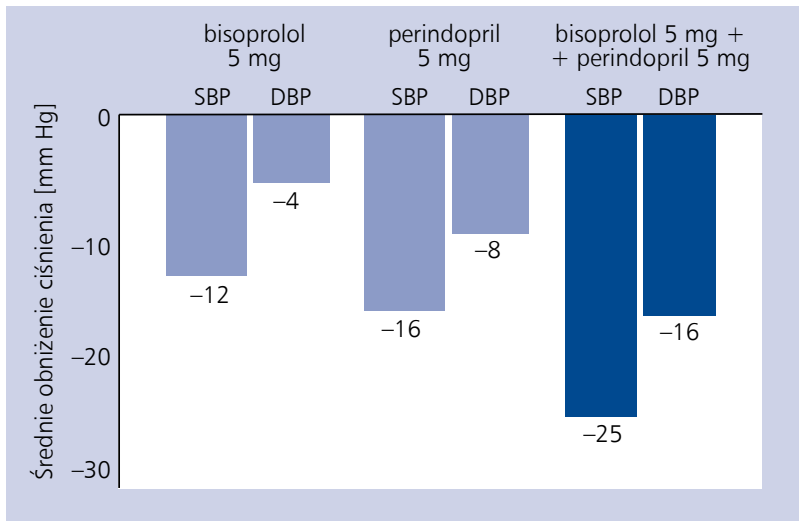

Rycina 5. Skuteczność hipotensyjna stosowania bisoprololu i perindoprilu w monoterapii lub leczeniu skojarzonym; DBP — ciśnienie rozkurczowe; SBP — ciśnienie skurczowe; na podstawie [16]

W wytycznych ESH/ESC z 2013 roku i PTNT z 2015 roku zarówno $\beta$-adrenolityki, jak i ACEI zaliczono do podstawowych grup leków hipotensyjnych przy rozpoczynaniu i kontynuacji leczenia hipotensyjnego. Omawiane grupy leków, a także ich skojarzenie mają ugruntowane miejsce w terapii pacjentów z nadciśnieniem tętniczym współistniejącym z chorobą wieńcową, po przebytym zawale serca lub z niewydolnością serca. W wytycznych PTNT z 2015 roku wskazano, że u osób bez rozpoznanej choroby możliwe jest zastosowanie $\beta$-adrenolityków, w tym także w skojarzeniu z ACEI u chorych z tachykardią i/lub zaburzeniami rytmu serca, a także u pacjentów z objawami krążenia hiperkinetycznego, szczególnie u osób młodszych. Dostępność omawianego skojarzenia w postaci preparatu złożonego może się z kolei przyczynić do poprawy stopnia stosowania się do zaleceń, który w terapii nadciśnienia tętniczego wciąż jest niezadowalający [1, 5]. W wytycznych PTNT z 2015 roku zwrócono uwagę na zalety stosowania preparatów złożonych:

- „W leczeniu skojarzonym warto wykorzystywać preparaty złożone, co pozwala na zwiększenie skuteczności leczenia, uproszczenie schematu leczenia i zwiększenie przestrzegania zaleceń terapeutycznych" [5];

— "Stosowanie preparatów złożonych dodatkowo zwiększa skuteczność hipotensyjną preparatu złożonego w stosunku do algorytmu monoterapii — terapia skojarzona, a jednocześnie mniejsze dawki minimalizują ryzyko wystąpienia zdarzeń niepożądanych, zależnych od wielkości dawki tych leków" [5].

Konflikt interesów: dotyczący udziału w konferencjach i wykładach organizowanych przez: Gedeon Richter, KRKA, Sandoz, Servier.

\section{Piśmiennictwo}

1. Mancia G, Fagard R, Narkiewicz K et al. 2013 ESH/ESC guidelines for the management of arterial hypertension: the Task Force for the Management of Arterial Hypertension of the European Society of Hypertension (ESH) and of the European Society of Cardiology (ESC). Eur Heart J, 2013; 34: 2159-2219.

2. Januszewicz A, Prejbisz A. Miejsce beta-adrenolityków o właściwościach naczyniorozszerzających $w$ terapii nadciśnienia tętniczego. Medical Education, Warszawa 2012.

3. Januszewicz A, Prejbisz A. Nadciśnienie tętnicze. Problemy współczesnej terapii w praktyce klinicznej. Medycyna Praktyczna, Kraków 2015.

4. Kaplan NM, Victor RG. Kaplan's clinical hypertension. Wolters Kluwer, Philadelphia 2015.

5. Tykarski A, Narkiewicz K, Gaciong Z et al. Zasady postępowania w nadciśnieniu tętniczym -2015 rok. Wytyczne Polskiego Towarzystwa Nadciśnienia Tętniczego. Nadciśnienie Tętnicze w Praktyce, 2015; 1: 1-70.

6. Suonsyrja T, Hannila-Handelberg T, Paavonen KJ et al. Laboratory tests as predictors of the antihypertensive effects of amlodipine, bisoprolol, hydrochlorothiazide and losartan in men: results from the randomized, double-blind, crossover GENRES Study. J Hypertens, 2008; 26: 1250-1256.

7. Wald DS, Law M, Morris JK et al. Combination therapy versus monotherapy in reducing blood pressure: meta-analysis on 11,000 participants from 42 trials. Am J Med, 2009; 122: 290-300.

8. Wong GW, Boyda HN, Wright JM. Blood pressure lowering efficacy of beta-1 selective beta blockers for primary hypertension. Cochrane Database Syst Rev, 2016; 3: CD007451.

9. Czuriga I, Riecansky I, Bodnar J et al. Comparison of the new cardioselective beta-blocker nebivolol with bisoprolol in hypertension: the Nebivolol, Bisoprolol Multicenter Study (NEBIS). Cardiovasc Drugs Ther, 2003; 17: 257-263.

10. Myers MG. A dose-response study of perindopril in hypertension: effects on blood pressure 6 and $24 \mathrm{~h}$ after dosing. Perindopril Multicentre Dose-Response Study Group. Can J Cardiol, 1996; 12: 1191-1196.

11. Tsoukas G, Anand S, Yang K. Dose-dependent antihypertensive efficacy and tolerability of perindopril in a large, observational, 12-week, general practice-based study. Am J Cardiovasc Drugs, 2011; 11: 45-55.

12. Ionescu DD. Antihypertensive efficacy of perindopril $5-10 \mathrm{mg} /$ day in primary health care: an open-label, prospective, observational study. Clin Drug Investig, 2009; 29: 767-776.

13. van Vark LC, Bertrand M, Akkerhuis KM et al. Angiotensin-converting enzyme inhibitors reduce mortality in hypertension: a meta-analysis of randomized clinical trials of renin-angiotensin-aldosterone system inhibitors involving 158998 patients. Eur Heart J, 2012; 33: 2088-2097.

14. Prejbisz A, Klocek M, Gasowski J et al. Trends for beta-blockers use in a large cohort of Polish hypertensive patients: Pol-Fokus study. Arterial Hypertens, 2015; 19: 120-128.

15. Prejbisz A, Klocek M, Gasowski J et al. Factors associated with resistant hypertension in a large cohort of hypertensive patients: the Pol-Fokus study. Pol Arch Med Wewn, 2015; 125: 249-259.

16. Madej A, Buldak L, Basiak M et al. The effects of 1 month antihypertensive treatment with perindopril, bisoprolol or both on the ex vivo ability of monocytes to secrete inflammatory cytokines. Int J Clin Pharmacol Ther, 2009; 47: 686-694.

17. Giles TD, Weber MA, Basile J et al. Efficacy and safety of nebivolol and valsartan as fixed-dose combination in hypertension: a randomised, multicentre study. Lancet, 2014; 383: 1889-1898. 